\title{
PENGARUH FAKTOR FUNDAMENTAL PERUSAHAAN TERHADAP RESIKO INVESTASI PADA PERUSAHAAN YANG GO PUBLIK DI BURSA EFEK INDONESIA
}

\author{
Oleh \\ Esli Silalahi
}

\begin{abstract}
Abstrak
Keputusan investasi dalam surat berharga bagi seorang investor menyangkut masa depan yang mengandung ketidakpastian, hal ini mengandung unsur resiko bagi investor. Pengetahuan tentang resiko merupakan suatu hal yang penting yang dimiliki oleh setiap investor maupun calon investor dalam mengambil keputusan di pasar modal. Pasar modal saat ini dipandang sebagai sarana bagi pendanaan usaha atau sebagai sarana bagi perusahaan untuk mendapatkan dana dari masyarakat pemodal atau investor. Investor sebelum melakukan investasi di pasar modal, akan mengumpulkan sebanyak mungkin informasi yang berguna dalam pengambilan keputusan investasi. Penelitian ini bertujuan untuk menganalisis pengaruh faktor fundamental perusahaan meliputi pertumbuhan aktiva, leverage keuangan ,likuiditas, price earning ratio terhadap resiko investasi pada perusahaan yang go publik di Bursa Efek Indonesia. Dalam penelitian ini, populasi yang digunakan adalah seluruh perusahaan manufaktur yang go publik di Bursa Efek Indonesia pada tahun 2009-2012. Metode pengambilan sampel yang digunakan adalah non probability sampling dengan tehnik purposive sampling dengan mengambil sampel berdasarkan kriteria, maksud dan tujuan penelitian.

Metode pengumpulan data yang digunakan dalam penelitian ini adalah tehnik Dokumentasi dilakukan dengan mengumpulkan dan mentabulasikan data yaitu berupa data laporan keuangan, tingkat yang dapat diakses melalui internet. Metode analisis yang digunakan adalah dengan regresi linear

Hasil penelitian menunjukkan bahwa Pengujian secara parsial bahwa faktor fundamental perusahaan meliputi : Pertumbuhan ekonomi berpengaruh positif dan tidak signifikan terhadap risiko investasi; Leverage keuangan berpengaruh positif dan signifikan terhadap risiko investasi ; Likuiditas berpengaruh positif dan tidak signifikan terhadap risiko investasi ; Price Earning Ratio berpengaruh positif dan signifikan terhadap risiko investasi. Pengujian secara simultan faktor fundamental perusahaan berpengaruh positif dan signifikan terhadap risiko investasi.
\end{abstract}

Kata Kunci : Keputusan Investasi, Faktor Fundamental, dan Resiko investasi

\section{Pendahuluan}

Selama dasawarsa terakhir, pasar modal Indonesia mulai menunjukkan peranan penting dalam memobilisasi dana untuk menunjang investasi dan pembangunan nasional. Akses dana dari pasar modal telah mengundang banyak perusahaan nasional maupun perusahaan patungan untuk menyerap dana masyarakat tersebut dengan tujuan beragam. Namun sasaran 
utamanya adalah meningkatkan produktivitas kerja melalui ekspansi usaha dan mengadakan pembenahan struktur modal untuk meningkatkan daya saing perusahaan.

Sejalan dengan semakin diminati pendanaan dari pasar modal, hal ini dapat membantu dalam era perdagangan bebas, lalu lintas keuangan internasional, dan keluar masuknya arus modal dan investasi. Kondisi tersebut mendorong percepatan pergerakan arus uang (flow of fund) dan arus modal (flow of capital) melintasi batas negara menuju negara yang iklim investasinya menjanjikan penghasilan (expected rate of return) yang paling tinggi dengan resiko yang relatif sama atau lebih kecil.

Pasar modal Indonesia dengan keterbatasan instrumen-instrumennya memungkinkan mobilisasi dana masih relatif terbatas jika dibandingkan dengan bursa-bursa dunia yang telah mapan, tetapi dapat menjadi wahana penting di luar perbankan untuk menyediakan dana yang diperlukan dunia usaha melalui penjualan saham dan obligasi serta derivatif. Keputusan investasi dalam surat berharga bagi seorang investor menyangkut masa depan yang mengandung ketidakpastian, berati mengandung unsur resiko bagi investor. Pengetahuan tentang resiko merupakan suatu hal yang penting yang dimiliki oleh setiap investor maupun calon investor dalam mengambil keputusan di pasar modal. Seorang investor rasional sebelum mengambil keputusan investasi paling tidak memperhatikan dua hal yaitu pendapatan yang diharapkan (expected return) dan resiko (risk) yang terkandung dari alternatif investasi yang dilakukan. (Nurdin : 1999).

Pada umumnya resiko selalu terdapat pada setiap alternatif investasi tetapi besar kecilnya resiko tersebut pada setiap alternatif investasi tergantung dari jenis investasinya dan perusahaan atau industri yang mengeluarkan surat berharga. Tingginya resiko investasi pada saham disebabkan oleh pendapatan yang diharapkan dari investasi saham bersifat tidak pasti, dimana pendapatan saham terdiri dari deviden dan capital gain. Sedangkan kesanggupan suatu perusahaan untuk membayar deviden ditentukan oleh kemampuan perusahaan dalam menghasilkan laba, sedangkan capital gain ditentukan oleh fluktuasi harga saham.

Kemampuan perusahaan menghasilkan laba dan fluktuasi harga saham dipengaruhi oleh faktor bersifat internal perusahaan dan eksternal perusahaan. Faktor-faktor yang bersifat internal perusahaan atau fundamental perusahaan adalah spesifik dan mempengaruhi perusahaan atau industri tertentu saja, seperti perubahan devidend payout ratio, pertumbuhan aktiva, leverage, likuditas, asset size, dan variabilitas keuntungan. 
Resiko investasi saham diartikan sebagai kemungkinan terjadinya perbedaan antara return aktual dengan return yang diharapkan dalam investasi saham. Resiko saham dibagi dalam dua golongan yaitu resiko sistematis (systematick risk) dan resiko tidak sistematis (unsystematic risk). Resiko sistematis adalah resiko return suatu saham yang berasal dari kondisi ekonomi dan kondisi pasar secara umum, yang tidak dapat didiversifikasikan atau resiko yang mempengaruhi banyak perusahaan sehingga sering disebut sebagai resiko pasar (market risk). Resiko yang termasuk dalam kelompok ini adalah resiko pasar, resiko tingkat bunga, resiko politik. Resiko ini tidak dapat dikurangi dengan cara diversifikasi, maka resiko ini relevan untuk mengukur investasi. Resiko sistematis ditentukan oleh besar kecilnya koefisien beta yang menunjukkan tingkat kepekaan harga suatu saham terhadap harga saham secara keseluruhan di pasar.

Kajian-kajian tentang faktor-faktor yang mempengaruhi resiko investasi (beta saham) telah banyak dilakukan, seperti beberapa variabel yang mempengaruhi beta saham sebagai parameter resiko investasi saham yaitu faktor fundamental perusahaan meliputi devidend payout ratio, leverage, likuiditas, asset growth. Sedangkan penelitian Tandelilin (1997), Dian (1998) dan Tjiang (1999) menunjukkan bahwa faktor fundamental berpengaruh terhadap resiko investasi, dimana devidend payout ratio dan asset growth berpengaruh signifikan terhadap resiko sistimatis (beta Saham). Penelitian Sitompul. C, at.,al menyatakan bahwa faktor-faktor fundamental yang terdiri dari Earning Per Share (EPS), Book Value Per Share (BVS), PriceEarning Ratio (PER), Debt to equity(DER), Return On Asset (ROA) dan Return on Equity (ROE) berpengaruh terhadap harga saham . Berdasarkan hasil penelitian, disimpulkan bahwa secara simultan faktor-faktor fundamental yang terdiri dari Earning Per Share (EPS), BookValue Per Share (BVS), Price Earning Ratio (PER), Debt to Equity Ratio (DER), Return On Asset (ROA) dan Return on Equity (ROE) berpengaruh terhadap harga saham. Secara parsial bahwa Earning Per Share (EPS), Book Value Per Share (BVS) dan Price Earning Ratio (PER) berpengaruh signifikan terhadap harga Saham perusahaan Real Estate dan Property yang Terdaftar di Bursa Efek Indonesia, sedangkan Debt to Equity Ratio (DER), Return On Asset (ROA) dan Return on Equity (ROE) tidak berpengaruh signifikan terhadap Harga Saham perusahaan

Beberapa penelitian yang berkenaan dengan pengaruh faktor Fundamental perusahaan dan factor fundamental ekonomi terhadap resiko investasi antara lain : William Beaver, Paul Kettler, Myron Scholes (1990) 
dalam penelitiaanya tentang " The Association Between Market Determined and Accounting Determined Risk Measures" faktor fundamental meliputi Devidend Payout, Asset Growth, Leverage , Liquidity, Asset Size, Earning Variability, dan Accounting Beta. Dari hasil penelitian mengatakan bahwa empat variabel meliputi Devidend Payout, Leverage, Earning Variability, dan Accounting Beta mempunyai berpengaruh terhadap resiko perusahaan yang di ukur dengan beta pasar.

Ziot dan Shalit (1990) juga melakukan penelitian mengenai faktorfaktor yang menentukan resiko equity. Resiko equity yang diukur dengan Earning Deviden, Beta, dan Stock Turnover. Dari hasil penelitian menunjukkan bahwa resiko equity mempunyai hubungan positif dengan leverage, dengan ukuran perusahaan dan deviden.

Analisis Fundamental merupakan suatu alat yang tepat untuk mengidentifikasi apakah perusahaan tersebut layak dan tidak untuk diberi dana atau untuk dijadikan objek investasi. Perusahaan Manufaktur dapat dijadikan obyek penelitian mengenai variabel fundamental karena pertumbuhan sektor manufaktur juga perlu investasi dari swasta maupun masyarakat untuk menunjang pertumbuhan sektor manufaktur sehingga dapat mencapai pertumbuhan yang meningkat dan pertumbuhan berbagai sektor manufaktur diharapkan dapat meningkatkan pertumbuhan ekonomi secara keseluruhan dimasa yang akan datang. Hasil Penelitian Dian (1998) meliputi Current Ratio, Tottal Asset Turn Over, Return On Equity, Debt to Equity Ratio, Net Profit Margin, dan Price Earning Ratio berpengaruh terhadap harga saham yang Go Public di Bursa Efek Indonesia

Resiko investasi saham menurut Tandelilin (2001) diartikan sebagai kemungkinan terjadinya perbedaan antara return aktual dengan return yang diharapkan dalam investasi saham. Resiko dalam saham dapat dibagi dua golongan yaitu resiko tidak sistematis (unsystematic risk) dan resiko sistematis (systematic risk). Resiko sistematis adalah resiko return saham yang berasal dari kondisi ekonomi dan kondisi pasar secara umum yang tidak dapat diversifikasi atau resiko yang mempengaruhi banyak perusahaan sehingga sering disebut dengan resiko pasar (market risk). Resiko ini termasuk dalam kelompok resiko tingkat suku bunga, resiko daya beli dan resiko politik. Resiko sistematis menunjukkan sensitifitas pergerakan return saham terhadap pergerakan return saham-saham lainnya di pasar. Resiko sistematis relevan untuk mengukur resiko investasi yang diukur dari beta saham hal ini sesuai dengan yang dikemukakan oleh Irhas Effendi dan Muafi (2001). 
Resiko Investasi yang diukur dari beta saham $(B)$ yaitu menunjukkan ukuran yang sensitivitas return saham individual terhadap perubahan return pasar (portofolio pasar) yang dilihat dari Nilai koefisien regresi sederhana dari return saham individual terhadap return pasar (metode single index models)

Langkah-langkah dalam menentukan resiko investasi sebagai berikut :

1. Tahap pertama adalah menghitung return saham individual dan return pasar secara bulanan. Perhitungan ini dilakukan untuk memperoleh tingkat pengembalian saham individual dan return pasar perbulan :

a. Perhitungan tingkat pengembalian saham individual $i\left(R_{i t}\right)$ pada periode $\mathrm{t}$

$$
R_{i t}=\frac{P_{i t}-P_{i t}-1}{P_{i t}-1}
$$

Keterangan :

$R_{i t}=$ Return saham individual i pada saat $\mathrm{t}$

$P_{i t}=$ Harga saham penutupan pada periode $\mathrm{t}$

$P_{i t-1}=$ Harga saham penutupan pada periode $\mathrm{t}-1$

b. Tingkat pengembalian bulanan dari saham-saham yang berada di bursa (market return) diukur dengan menggunakan pendekatan Indeks Harga Saham Gabungan (IHSG). Perhitungan return atau tingkat pengembalian dari saham-saham di bursa $\left(R_{m t}\right)$ dihitung menggunakan rumus menurut Siddharta Utama (1998), Prihat Asih (2000) sebagai berikut :

$R_{m t}=\frac{I H S G_{t}-I S H G_{t-1}}{I H S G_{t-1}}$

Keterangan :

$R_{m t}=$ Return pasar saat $\mathrm{t}$

$I H S G_{t}=$ Indeks harga pasar pada periode $\mathrm{t}$

$I H S G_{t-1}=$ Indeks harga pasar pada periode $\mathrm{t}-1$

2. Tahap kedua adalah menghitung resiko sistematis dari setiap saham. Resiko sistematis dari suatu saham diukur berdasarkan kepekaan pergerakan return suatu saham terhadap return dari saham-saham di bursa (market return) dari portofolio pasar. Estimasi dari resiko sistematis atau beta dapat dihitung melalui model indeks tunggal (single index model). Model indek tunggal menyatakan bahwa ada hubungan linier antara return suatu saham i $\left(R_{i t}\right)$ dengan return dari pasar $\left(R_{m t}\right)$ pada periode $\mathrm{t}$, dinyatakan sebagai berikut :

$$
R_{i t}=\alpha_{i}+\beta_{i} R_{m t}+\varepsilon_{i t}
$$


Dimana :

$R_{i t}=$ Tingkat keuntungan saham i pada periode $\mathrm{t}$

$R_{m t}=$ Tingkat keuntungan pasar $\mathrm{m}$ pada periode $\mathrm{t}$

$\alpha_{i}=$ Intercept

$\beta_{i}=$ Beta saham i

$\varepsilon_{i t}=$ Faktor penganggu (Epsilon)

Dalam penelitian ini yang dimaksud dengan faktor fundamental perusahaan adalah faktor-faktor yang berkaitan dengan kinerja keuangan perusahaan dalam bentuk rasio keuangan. Hal ini sesuai dengan yang dikemukakan Roy Sembel (2001) bahwa faktor fundamental perusahaan adalah faktor yang secara spesifik mencerminkan dan atau mempengaruhi kinerja perusahaan dalam bentuk indikator finansial. Hal sama dikemukakan oleh Jogiyanto (1998) bahwa data fundamental adalah datadata yang berasal dari laporan keuangan perusahaan (misalnya laba, deviden yang dibagikan, penjualan dan lainnya).

Dalam teori, salah satu cara melakukan analisis investasi dalam bentuk saham adalah dengan analisis fundamental. Analisis fundamental menyatakan bahwa setiap investasi saham mempunyai landasan yang kuat yang disebut dengan nilai instrinsik yang dapat ditentukan melalui suatu analisis terhadap kondisi perusahaan pada saat sekarang dan prospeknya di masa mendatang. Nilai instrinsik merupakan suatu fungsi dari faktorfaktor perusahaan yang dikombinasikan untuk menghasilkan suatu keuntungan yang diharapkan dengan suatu resiko yang melekat pada saham tersebut.

Analisis fundamental adalah metode analisis yang didasarkan pada fundamental ekonomi suatu perusahaan. Teknis ini menitik beratkan pada rasio finansial dan kejadian- kejadian yang secara langsung maupun tidak langsung mempengaruhi kinerja keuangan perusahaan. Sebagian pakar berpendapat teknik analisis fundamental lebih cocok untuk membuat keputusan dalam memilih saham perusahaan mana yang dibeli untuk jangka panjang. Analisis fundamental dibagi dalam tiga tahapan analisa yaitu analisis ekonomi, analisis industri, dan analisis perusahaan. Secara umum, analisis fundamental ini melibatkan banyak sekali variabel data yang harus dianalisa, di mana beberapa di antara variabel tersebut yang cukup penting untuk diperhatikan yaitu : (http://id.wikipedia.org/wiki) :

- Pertumbuhan pendapatan (revenue growth)

- Rasio laba terhadap saham yang beredar ( earning per share-EPS)

- Rasio pertumbuhan EPS 
- Rasio harga saham terhadap laba perlembar saham (price earning ratio)

- Rasio harga saham terhadap pertumbuhan laba perseroan (price earning growth ratio)

- Rasio harga saham terhadap penjualan (price/sales ratio)

- Rasio harga saham terhadap nilai buku (price book value)

- Rasio hutang perseroan (debt ratio)

- Margin pendapatan bersih (net profit margin)

- Analisa fundamental memberi pengaruh kepada trend perubahan harga (arah dari harga suatu mata uang secara keseluruhan) yang lebih banyak dipengaruhi oleh kebijakan-kebijakan yang dilakukan pemerintah (otoritas moneter) ataupun data-data yang dirilis oleh berbagai sumber maupun berita-berita tertentu yang belum pasti kebenarannya (market sentiment and market rumors).

Faktor pertama yang diduga berpengaruh terhadap resiko investasi yang diwakili resiko sistematis (beta saham) adalah pertumbuhan aktiva (assets growth). Pertumbuhan aktiva merupakan perubahan atau tingkat pertumbuhan tahunan dari total aktiva. Bank yang sedang berkembang sangat membutuhkan dana yang besar untuk operasionalnya. Pertumbuhan aktiva yang cepat mengindikasikan bahwa bank sedang mengadakan perluasan usaha atau ekspansi. Apabila bank dalam ekspansinya tidak mencapai sasaran yang telah ditentukan oleh bank maka akan mengakibatkan beban bank. Pertumbuhan aktiva merupakan tingkat pertumbuhan aktiva emiten perusahaan.

$P A_{t}=\frac{T A_{t}-T A_{t-1}}{T A_{t-1}}$

Keterangan :

$P A_{t}=$ Pertumbuhan aktiva pada tahun $\mathrm{t}$

$T A_{t}=$ Total aktiva pada tahun $\mathrm{t}$

$T A_{t-1}=$ Total aktiva pada tahun $\mathrm{t}-1$

Faktor kedua yang mempengaruhi resiko investasi adalah leverage keuangan. Leverage keuangan pada perbankan berkaitan dengan penggunaan dana pihak ketiga (hutang) dalam menjalankan operasionalnya. Leverage keuangan bertujuan untuk meningkatkan keuntungan perusahaan. Semakin tinggi leverage keuangan akan meningkatkan resiko investasi yang akan ditanggung investor. Hal tersebut dikarenakan banyaknya dana yang berasal dari pihak ketiga menunjukkan bahwa bank memperoleh manfaat untuk memutar dana 
tersebut. Apabila perbankan menggunakan dana pihak ketiga (hutang) semakin besar, maka makin besar beban tetap berupa bunga yang harus dibayar. Semakin besar proporsi hutang yang dipergunakan semakin besar leverage keuangan dan semakin besar resiko investasi yang ditanggung investor, artinya leverage keuangan mempunyai kaitan yang positif dengan resiko investasi.

$$
\text { Leverage }=\frac{\text { Total Liabilities }}{\text { Total Assets }}
$$

Faktor ketiga yang mempengaruhi resiko investasi adalah likuiditas. Likuiditas berkaitan dengan kemampuan perusahaan dalam memenuhi kewajiban hutang-hutang Likuiditas adalah kemampuan perusahaan dalam membayar kewajiban jangka pendek yang segera jatuh tempo. Likuiditas diukur dengan Curent ratio merupakan indikator jangka pendek terhadap kemampuan perusahaan untuk membayar kewajiban-kewajiban jangka pendeknya dengan menggunakan aktiva lancar yang tersedia (Syamsyudin,2007). Dengan kata lain, seberapa besar aktiva lancar yang tersedia mampu menutup dengan segera kewajiban lancarnya. Curent ratio yang semakin tinggi menunjukkan semakin besar kemampuan perusahaan untuk memenuhi kewajiban finansial jangka pendeknya. Meythi (2006) membuktikan bahwa current ratio yang paling baik dalam memprediksi return saham perusahaan manufaktur. Hasil serupa juga di peroleh dari hasil penelitian Wiksuana (2008). Sebaliknya, Wira (2008) menyatakan bahwa current ratio tidak mempunyai pengaruh terhadap return saham. Likuiditas dapat dihitung dari current ratio sebagai berikut :

$$
\text { Current Ratio }=\frac{\text { Current Assets }}{\text { Current Liabilities }}
$$

Faktor keempat yang mempengaruhi risiko investasi adalah price earning ratio. Kemampuan investor memilih saham secara rasional dapat diukur dari sejauhmana investor tersebut berhasil memilih saham yang memberikan hasil maksimal pada risiko tertentu, sehingga investor berpendapat bahwa laba yang tidak stabil dan fkluktuasi laba yang tinggi kurang menarik dibandingkan dengan laba yang stabil dan fluktuasi laba yang rendah dalam melakukan investasi.Beaver, Kettler dan Scholes dalam Aristanto Eko (2002) .

Risiko perusahaan terlihat pada price earning ratio yang menggunakan rasio antara harga pasar suatu saham (market price) dengan (earning per sharer). Perusahaan yang diharapkan tumbuh dengan tingkat pertumbuhan yang tinggi (berarti mempunyai prospek yang lebih baik), mempunyai PER 
yang tinggi juga. Sebaliknya, perusahaan yang di harapkan mempunyai pertumbuhan yang rendah akan mempunyai PER yang rendah juga,Hanafi, (2005) dalam Arian Absari,D.Y. (2012)

Price Earning Ratio (PER) $=\frac{\text { Harga Per Lembar Saham }}{\text { Laba Per Lembar Saham }}$

Penelitian ini bertujuan untuk mengetahui pengaruh faktor fundamental perusahaan meliputi Pertumbuhan Aktiva (AG), Leverage (Lev), Likuiditas (LQ) dan Price Earning Ratio (PER) terhadap resiko investasi pada perusahaan yang Go Publik di Bursa Efek Indonesia.

\section{Metodologi Penelitian}

Populasi adalah keseluruhan unsur-unsur atau data yang akan diteliti atauyang dijadikan sebagai obyek penelitian. Dalam penelitian ini, populasi yang digunakan adalah seluruh perusahaan manufaktur yang go publik di Bursa Efek Indonesia pada tahun 2009-2012. Metode pengambilan sampel yang digunakan adalah non probability sampling dengan tehnik purposive sampling dengan mengambil sampel berdasarkan kriteria, maksud dan tujuan penelitian. Kriteria sampel adalah sebagai berikut : (1).Perusahaan yang dipilih adalah perusahaan jenis manufaktur yang telah go publik di Bursa Efek Indonesia selama periode tahun 2009 sampai tahun 2012 yang sahamnya aktif diperdagangkan di BEI; (2). Perusahaan manufaktur yang telah menerbitkan laporan keuangan yang lengkap yang telah diaudit pada Bursa Efek Indonesia selama periode tahun 2009 sampai periode tahun 2012; (3). Perusahaan manufaktur yang mempunyai laba positif selama periode tahun 2010 sampai tahun 2012; (4) Perusahaan manufaktur yang memiliki data sesuai sengan variabel penelitian selama periode tahun 2009 sampai dengan tahun 2012.

\section{Operasionalisasi variabel}

Adapun operasionalisasi variabel dalam penelitian adalah

1. Pertumbuhan aktiva merupakan tingkat pertumbuhan aktiva emiten perusahaan yang di ukur dari :

$$
\frac{\text { Total Aktiva } t-\text { Total Aktiva }_{t-1}}{\text { Total Aktiva }}
$$

2. Leverage keuangan yaitu kemampuan emiten dibiayai hutang yang diukur

$$
\text { dari : } \frac{\text { Total Liabilities }}{\text { Total Assets }}
$$


3. Likuiditas yaitu kemampuan bank untuk membayar kembali simpanan nasabah yang diukur dari : $\frac{\text { Current Assets }}{\text { Current Liabilities }}$

4. Price Earning Ratio : Megukur berapa banyak jumlah dana yang dikeluarkan oleh investor atas setiap laba perusahaan., yang diukur dari: PER $=\frac{\text { Harga Per Lembar Saham }}{\text { Laba Per Lembar Saham }}$

5. Resiko Investasi yang diukur dari beta saham $(B)$ yaitu menunjukkan ukuran yang sensitivitas return saham individual terhadap perubahan return pasar (portofolio pasar) yang dilihat dari Nilai koefisien regresi sederhana dari return saham individual terhadap return pasar (metode single index models)

Langkah-langkah dalam menentukan resiko investasi sebagai berikut :

1. Tahap pertama adalah menghitung return saham individual dan return pasar secara bulanan. Perhitungan ini dilakukan untuk memperoleh tingkat pengembalian saham individual dan return pasar perbulan :

a. Perhitungan tingkat pengembalian saham individual $i\left(R_{i t}\right)$ pada periode $\mathrm{t}$

$$
R_{i t}=\frac{P_{i t}-P_{i t}-1}{P_{i t}-1}
$$

Keterangan :

$R_{i t}=$ Return saham individual i pada saat $\mathrm{t}$

$P_{i t}=$ Harga saham penutupan pada periode $\mathrm{t}$

$P_{i t-1}=$ Harga saham penutupan pada periode $\mathrm{t}-1$

b. Tingkat pengembalian bulanan dari saham-saham yang berada di bursa (market return) diukur dengan menggunakan pendekatan Indeks Harga Saham Gabungan (IHSG). Perhitungan return atau tingkat pengembalian dari saham-saham di bursa $\left(R_{m t}\right)$ dihitung menggunakan rumus menurut Siddharta Utama (1998), Prihat Asih (2000) sebagai berikut :

$R_{m t}=\frac{I H S G_{t}-I S H G_{t-1}}{I H S G_{t-1}}$

Keterangan :

$R_{m t}=$ Return pasar saat $\mathrm{t}$

$I H S G_{t}=$ Indeks harga pasar pada periode $\mathrm{t}$

$I H S G_{t-1}=$ Indeks harga pasar pada periode $\mathrm{t}-1$

2. Tahap kedua adalah menghitung resiko sistematis dari setiap saham. Resiko sistematis dari suatu saham diukur berdasarkan kepekaan pergerakan return suatu saham terhadap return dari saham-saham di 
bursa (market return) dari portofolio pasar. Estimasi dari resiko sistematis atau beta dapat dihitung melalui model indeks tunggal (single index model). Model indek tunggal menyatakan bahwa ada hubungan linier antara return suatu saham i $\left(R_{i t}\right)$ dengan return dari pasar $\left(R_{m t}\right)$ pada periode $\mathrm{t}$, dinyatakan sebagai berikut :

$R_{i t}=\alpha_{i}+\beta_{i} R_{m t}+\varepsilon_{i t}$

Dimana :

$R_{i t}=$ Tingkat keuntungan saham i pada periode $\mathrm{t}$

$R_{m t}=$ Tingkat keuntungan pasar $\mathrm{m}$ pada periode $\mathrm{t}$

$\alpha_{i}=$ Intercept

$\beta_{i}=$ Beta saham i

$\varepsilon_{i t}=$ Faktor penganggu (Epsilon)

\section{Tehnik analisis}

Tehnik analisis data yang digunakan adalah regresi linear berganda dengan model :

$B E T A_{i, t}=\beta_{0}+\beta_{1} A G_{i, t}+\beta_{2} L E V_{i, t}+\beta_{3} L Q_{i, t}+\beta_{4} P E R_{i, t}+\varepsilon_{i}$

$B E T A_{i, t}=$ Resiko Investasi (Beta Saham) untuk perusahaan ke i pada tahun ke- t. $\beta_{1} A G_{i, t}=$ Asset Growth (Pertumbuhan Aktiva) untuk perusahaan ke i pada tahun ke- $\mathrm{t}$

$L E V_{i, t}=$ Leverage untuk perusahaan ke i pada tahun ke- $\mathrm{t}$

$L Q_{i, t}=$ Likuiditas untuk perusahaan ke i pada tahun ke- $\mathrm{t}$

$\beta_{4} P E R_{i, t}=$ price Earnung Ratio untuk perusahaan ke i pada tahun ke- $\mathrm{t}$

$\varepsilon_{i}=$ Faktor penganggu perubahan

\section{Hasil dan Pembahasan}

Penelitian ini bertujuan untuk mengetahui pengaruh faktor fundamental perusahaan terhadap resiko investasi pada perusahaan manufakture di bursa Efek Indonesia tahun 2009-2012. Variabel depanden adalah resiko investasi yang diukur dari beta saham, sedangkan variabel independen adalah faktor fundamental perusahaan yang di ukur dari pertumbuhan aktiva, Leverage keuangan ,Likuiditas dan price earning ratio. Sebelum lakukan analisis data langkah pertama adalah dengan melakukan ujiasumsi klasik yang ditunjukkan pada Tabel 1, Tabel 2 dan 
Gambar 1 sebagai berikut :

Tabel 1. Uji Multikoloniaritas

\begin{tabular}{|c|c|}
\hline Variabel & Nilai variance inflation factor (VIF) \\
\hline AG & 1,008 \\
\hline LEV & 1,043 \\
\hline LQ & 1,052 \\
\hline PER & 1,006 \\
\hline
\end{tabular}

Hasil perhitungan nilai tolerance ditunjukkan pada Tabel 1 dimana masing- masing variabel bebas, memiliki nilai variance inflation factor (VIF) kurang dari 0,10 atau lebih dari 10. Sehingga disimpulkan bahwa tidak terdapat multikoloniaritasantar variable pertumbuhan aktiva, leverage, likuiditas dan price earning ratio.

Tabel 2. Uji Autokorelasi Model Summary ${ }^{\mathrm{b}}$

\begin{tabular}{|c|c|c|c|c|c|}
\hline Model & $\mathrm{R}$ & R Square & $\begin{array}{l}\text { Adjusted R } \\
\text { Square }\end{array}$ & $\begin{array}{l}\text { Std. Error of the } \\
\text { Estimate }\end{array}$ & Durbin-Watson \\
\hline 1 & $.547^{a}$ & .299 & .019 & .053581 & 2.019 \\
\hline
\end{tabular}

a. Predictors: (Constant), PER, LEV, LQ, AG

b. Dependent Variable: BETA

Nilai Durbin watson sebesar 2,017 dibandingkan dengan nilai tabel dengan menggunakan nilai siqnifikan si 5\%, nilai DL sebesar 0,69 dan DU 1,97, dimana DW $>$ DU dan DW $<$ 4-DU. Dari hasi di atas disimpulkan tidak terdapat autokorelasi yang positif ataupun autokorelasi negatif.

Gambar 1. Uji Normalitas 


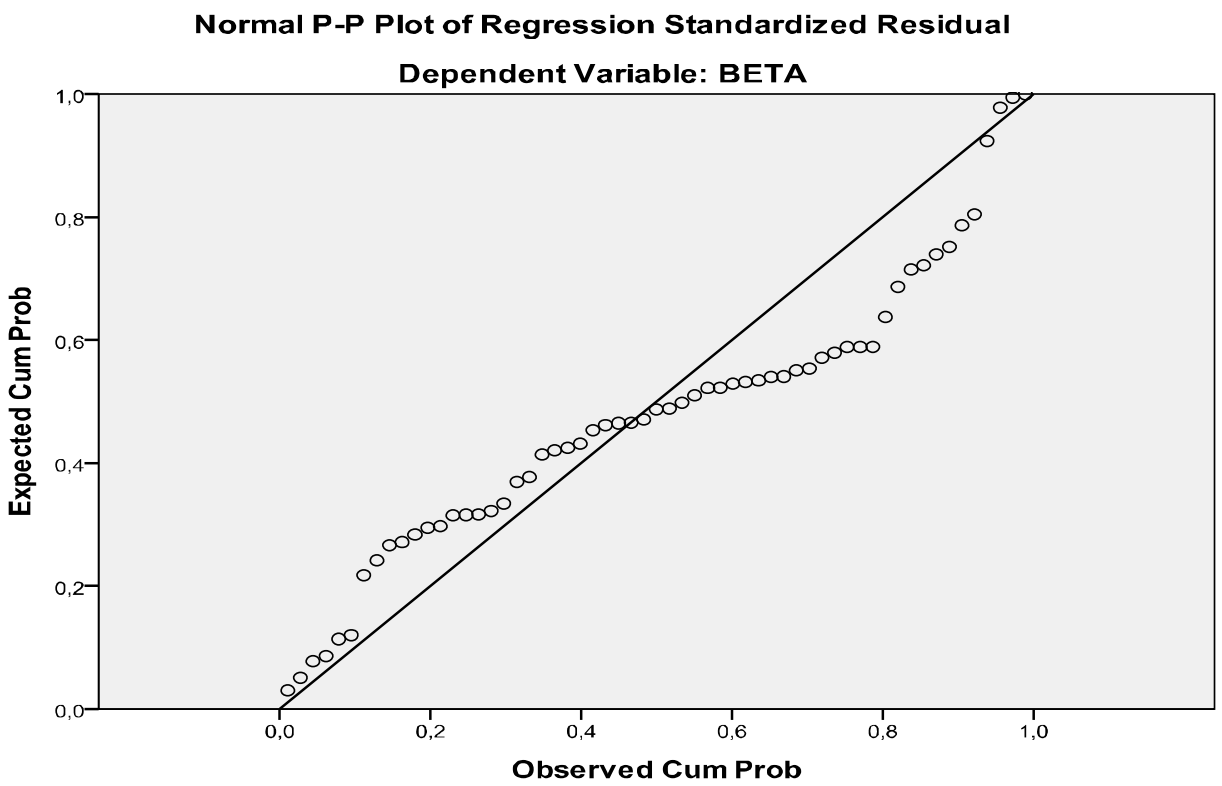

Setelah melakukan pengujian asumsi klasik, maka dilakukan pengujian penelitian dengan menggunakan analisis regresi linear berganda. Hasil perhitungan regresi linear berganda dalam penelitian ini ditunjukkan pada Tabel 3 berikut ini.

Tabel 3

Hasil Analisis Regresi Berganda

\begin{tabular}{|l|c|c|c|c|c|}
\hline \multicolumn{1}{|c|}{ Variabel } & $\begin{array}{c}\text { Nilai } \\
\text { Koefisien }\end{array}$ & $\begin{array}{c}\text { Standard } \\
\text { Error }\end{array}$ & Beta & t-value & $p$-value \\
\hline Konstanta & 0,739 & 0,047 & & 15,694 & 0,000 \\
Pertumbuhan Aktiva (AG) & 0,030 & 0,021 & 0,160 & 1,408 & 0,165 \\
Leverage (LEV) & 0,235 & 0,077 & 0,351 & 3,027 & 0,004 \\
Likuiditas (LQ) & 0.003 & 0,003 & 0,150 & 1,286 & 0,204 \\
Price Earning Ratio (PER) & 0.001 & 0,000 & 0,379 & 3,328 & 0,002 \\
& & & & & $p=0,000$ \\
\hline
\end{tabular}

Sumber: data sekunder diolah

Persamaan regresi dari hasil pengujian pertama adalah: $\mathrm{Y}=0,739+0,030 \mathrm{AG}+0,235 \mathrm{LEV}+0,003 \mathrm{LQ}+0,001 \mathrm{PER}+e$ 
Hasil analisis regresi menunjukkan pertumbuhan aktiva, leverage, likuiditas dan price eraning ratio berpengaruh terhadap risiko investasi.. Pengujian secara parsial dapat dilihat bahwa pertumbuhan aktiva (AG) berpengaruh positif dan tidak signifikan, Leverage keuangan (LEV) berpengaruh positif dan signifikan. Likuiditas (LQ) berpengaruh positif dan tidak signifikan sedangkan price earning ratio berpengaruh positif dan signifikan. Pengujian secara simultan ditunjukkan dari Nilai $F$ hitung sebesar 5,940 dengan signifikansi sebesar $p=0,000$. Hasil penelitian ini didukung penelitian Aristanto Eko (2002), Meythi (2006) dan Hanafi (2005) dalam Arian Absari D.Y (2012).

Hasil perhitungan menunjukkan bahwa nilai koefisien determinasi $\left(R^{2}\right)$ sebesar $30,58 \%$, hal tersebut menunjukkan bahwa besarnya variasi risiko investasi dapat dijelaskan oleh pertumbuhan aktiva, leverage, likuiditas dan price earning ratio sedangkan 69,42 \% lagi dapat dijelaskan oleh faktor lain. Rendahnya koefisien determinasi ini menunjukkan bahwa faktor fundamental perusahaan hanya merupakan sebagian dari faktor yang dapat mempengaruhi resiko investasi pada perusahaan manufaktur di Bursa Efek Indonesia.

Berdasarkan hasil olahan data juga dijelaskan pengujian secara parsial, yaitu menguji pengaruh faktor fundamental meliputi pertumbuhan aktiva (AG), leverage keuangan (LeV), likuiditas (LQ), dan Price Earning Ratio (PER) terhadap resiko investasi (Beta Saham) secara parsial pada perusahaan manufakture di Bursa Efek indonesia.

Hasil perhitungan menunjukkan pertumbuhan aktiva mempunyai nilai koefisien sebesar 0,030, hal ini menunjukkan bahwa pertumbuhan aktiva berpengaruh tetapi tidak signifikan terhadap resiko investasi. Dari hasil pengujian hipotesis menunjukkan nilai t hitung sebesar 1,408 dan t tabel sebesar 1,9600, dimana $\mathrm{t}$ hit $<\mathrm{t}$ tabel bahwa pertumbuhan aktiva mempunyai pengaruh yang tidak signifikan terhadap resiko investasi. Hasil penelitian ini sesuai dengan penelitian Dian (1998), Tjiang (1999) yang menyatakan bahwa pertumbuhan aktiva berpengaruh positif terhadap resiko investasi.

Hasil perhitungan menunjukkan leverage keuangan mempunyai nilai koefisien sebesar 0,236, hal ini menunjukkan bahwa leverage berpengaruh secara parsial terhadap resiko investasi. Dari hasil pengujian hipotesis menunjukkan nilai t hitung sebesar 3,027 dan $t$ tabel sebesar 1,960 , dimana $t$ hi $t>t$ tabel bahwa leverage mempunyai pengaruh yang signifikan terhadap resiko investasi. Hasil penelitian ini sesuai dengan penelitian Dian (1998), Tjiang (1999), Sitompul at,al (2010) yang 
menyatakan bahwa leverage berpengaruh positif terhadap resiko investasi. Peningkatan leverage yang relatif besar menunjukkan besarnya penggunaan dana dari pihak ketiga dalam membiayai aktiva suatu bank yang akan memberikan resiko yang tinggi yang akan dihadapi oleh pihak manajemen.

Hasil perhitungan menunjukkan likuiditas mempunyai nilai koefisien sebesar 0,003, hal ini menunjukkan bahwa likuiditas berpengaruh secara parsial terhadap resiko investasi. Dari hasil pengujian hipotesis menunjukkan nilai t hitung sebesar 1,286 dan t tabel sebesar 1,960, dimana $\mathrm{t}$ hit $<\mathrm{t}$ tabel bahwa likuiditas mempunyai pengaruh yang tidak signifikan terhadap resiko investasi. Hasil penelitian ini sesuai dengan penelitian Dian (1998), Tjiang (1999) yang menyatakan bahwa likuiditas berpengaruh positif terhadap resiko investasi.

Hasil perhitungan menunjukkan price earning ratio mempunyai nilai koefisien sebesar 0,001 , hal ini menunjukkan bahwa price earning ratio berpengaruh secara parsial terhadap resiko investasi. Dari hasil pengujian hipotesis menunjukkan nilai $\mathrm{t}$ hitung sebesar 3,328 dan $\mathrm{t}$ tabel sebesar 1,960, dimana $t$ hit $>t$ tabel bahwa price earning ratio mempunyai pengaruh yang signifikan terhadap resiko investasi. Hasil penelitian ini sesuai dengan penelitian Endah (1996) yang menyatakan bahwa variabilitas laba berpengaruh positif terhadap resiko investasi.

\section{KESIMPULAN DAN SARAN}

\section{Kesimpulan}

1. Pertumbuhan aktiva, likuiditas secara parsial berpengaruh positif tetapi tidak signifikan terhadap risiko investasi pada perusahaan manufakture yang go publik di Bursa Efek Indonesia.

2. Leverage keuangan, price earning ratio secara parsial berpengaruh positif dan signifikan terhadap risiko investasi pada perusahaan manufakture yang go publik di Bursa Efek Indonesia.

3. Pertumbuhan aktiva, leverage keuangan, likuiditas dan price earning ratio secara simultan berpengaruh positif dan signifikan terhadap risiko investasi pada perusahaan manufakture yang go publik di Bursa Efek Indonesia. 


\section{Saran}

Dengan melihat variabel-variabel yang mempengaruhi resiko investasi dalam hal ini beta saham pada perusahaan manufakture yang go publik di Bursa Efek Indonesia, sebaiknya investor sebelum melakukan keputusan investasi saham perusahaan manufakture harus memperhatikan faktor-faktor fundamental secara bersama-sama untuk dipertimbangkan seperti pertumbuhan aktiva, leverage, likuiditas dan price earning ratio.

\section{DAFTAR PUSTAKA}

Absari Dyatri Utami Arian, 2012. Analisis Pengaruh Faktor Fundamental Perusahaan Dan Risiko Sistematis Terhadap Return Saham Pada Perusahaan Manufaktur yang Listing Di Bursa Efek Indonesia Periode 2008-2011. Thesis Universitas Brawijaya Malang. http:// ejournal.uin-malang.ac.id/index.php/el.../article/.Di Akses 10 Desember 2013

Aristanto Eko, 2002. Pengaruh Faktor Fundamental Perusahaan dan Fundamental Ekonomi Terhadap Risiko Investasi Pada Saham Sektor Perbankan Yang Go Public Di Bursa Efek Jakarta Periode 19941999. Thesis Pascasarjana Universitas Padjadjaran bandung

Beaver, P.Kettler, dan M. Scholes, The Association Between Market Determined and Accounting Determined Risk Measures, Accounting Review 45, (October 1970), Hal 654-682.

Brigham Eugene F. \& Houston Joel F, 2006. Dasar-Dasar Manajemen Keuangan Terjemahan Ali

Akbar Yulianto, Edisi kesepuluh Jakarta: Salemba Empat

Dian, R.2009. Analisis Pengaruh Faktor-faktor fundamental Terhadap Harga Saham Studi pada Perusahaan Yang masuk Kategori LQ 45 Periode 2008. Undergraduate thesis, University of Muhammadiyah Malang. http://eprints.umm.ac.id/id/eprint/2749. Di Akses 20 September 2013.

Husnan, S. 2005. Dasar-Dasar Teori Portfolio dan Analisis Sekuritas, Edisi Ketiga. Unit Penerbit dan Percetakan UNP YKPN. Yogyakarta.

Meythi. 2007. Rasio Keuangan Yang Paling Baik Untuk Memprediksi Return Saham, Jurnal Bisnis Dan Akuntansi hal : 47-65.

Martono \& Agus Harjito, 2001. Manajemen Keuangan. Edisi Pertama, Yogyakarta : Penerbit Ekonesia

Sembel, Roy. 2001. Indikator Fundamental, Jurnal Pasar Modal Indonesia, Edisi Maret, Jakarta. Jakarta stock Echange.

Syahrir, 1995. Tinjauan Pasar Modal Jakarta, PT. Gramedia Pustaka Umum 
Sitompul, K., A. F. Lubis,. And S. Fauzie, 2010. Analisis Pengaruh Faktor-faktor Fundamental Terhadap Harga Saham Perusahaan Real Estate dan Property yang terdaftar Di Bursa Efek Indonesia. http:// repository.usu.ac.id. Di akses 20 Mei 2011.

Syamsudin, L. 2007. Manajemen Keuangan Perusahaan, Edisi Baru. PT. Raja Grafindo Persada. Jakarta.

Tandelilin, E. 2010. Portofolio dan Investasi, Edisi Pertama. KANISIUS (Anggota IKAPI). Yogyakarta.

Warsono. 2008. Kontribusi Pasar Modal terhadap Perekonomian Indonesia, Economics Bulletin Usahawan XXXVII .

Wiksuana, I Gst. Bgs. 2008. Pengaruh Faktor-faktor Fundamental terhadap Return Saham di Bursa Efek Indonesia, Jurnal Bisnis dan Manajeman hal : 401-411.

Wira, V. 2008. Analisa Karakteristik Perusahaan Terhadap Return dan Beta Perusahaan Makanan dan Minuman di Bursa Efek Jakarta, Jurnal Bisnis dan Manajeman hal : 1-110. 